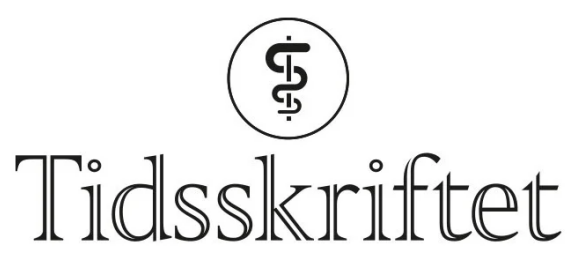

DEN NORSKE LEGEFORENING

\title{
Fallgruver ved hurtigtester av rusmidler
}

DEBATT

\section{JOACHIM FROST}

joachim.frost@stolav.no

Joachim Frost er ph.d., spesialist i klinisk farmakologi, overlege ved Avdeling for klinisk farmakologi, St. Olavs hospital og førsteamanuensis ved Institutt for klinisk og molekylær medisin, NTNU.

Forfatteren har fylt ut ICMJE-skjemaet og oppgir følgende interessekonflikter: Han arbeider ved en laboratorieavdeling som driver med analysevirksomhet, men har ingen direkte personlig $ø$ konomisk vinning av analysevirksomheten.

\section{TRINE MIKKELSEN}

Trine Mikkelsen er konstituert overlege ved Avdeling for rusmedisin, Helse Bergen. Forfatteren har fylt ut ICMJE-skjemaet og oppgir ingen interessekonflikter.

\section{Hurtigtester er en kilde til feil og misforståelser i oppfølgingen av rusmiddelbruk.}

Det finnes en rekke hurtigtester for rusmiddelanalyser. Felles for disse er at de baserer seg på uspesifikke immunologiske analyseprinsipper. Fordelen er raske svar, vanligvis i løpet av 5-10 minutter. Testene er imidlertid beheftet med flere begrensninger, blant annet stor risiko for både falskt positive og falskt negative resultater, risiko for brukerfeil og begrensninger i analyserepertoar. Dette er tidligere omtalt i Tidsskriftet og har vært et vedvarende fokusområde i informasjonsarbeid og kunnskapsformidling fra fagmiljøene innen rusmiddeltesting i Norge $(\underline{1}, \underline{2})$. Til tross for dette fortsetter bruken av hurtigtester å medføre fare for misforståelser og tolkningsfeil, også innenfor spesialisthelsetjenesten.

\section{Noen eksempler}

Figur 1 illustrerer noen fallgruver ved én slik hurtigtest for urin (SureScreen Diagnostics Ltd., Multi Drug Screen Test Panel), men de samme prinsippene gjelder også hurtigtester for spyttprøver. Den aktuelle testen er benyttet ved en institusjon innen tverrfaglig spesialisert rusbehandling. Test A viser falskt positivt resultat for amfetamin etter inntak av antibiotikumet ciprofloksacin. Dette på grunn av utilsiktet kryssreaktivitet. Test B viser manglende deteksjon av opioidet oksykodon kort etter inntak. Her er årsaken manglende antistoff mot oksykodon i testen. Testene $\mathrm{C}$ og D viser positivt resultat for morfin etter 
inntak av henholdsvis kodein og etylmorfin, som begge omdannes til morfin i kroppen etter inntak, og illustrerer hvordan testen ikke kan skille mellom inntak av kodein, etylmorfin og morfin.

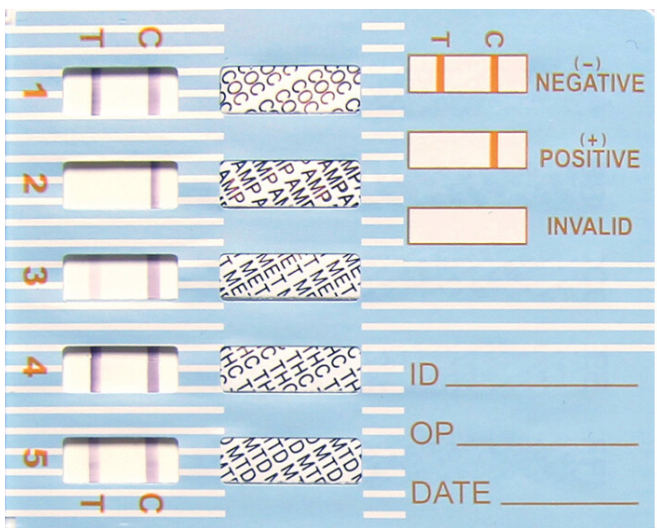

a

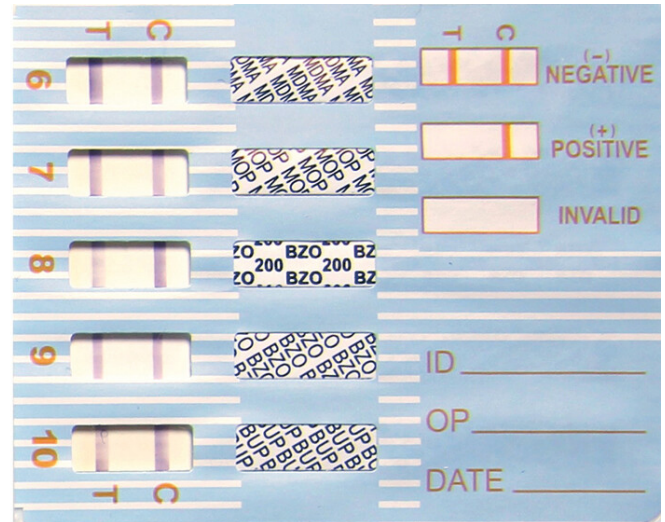

b

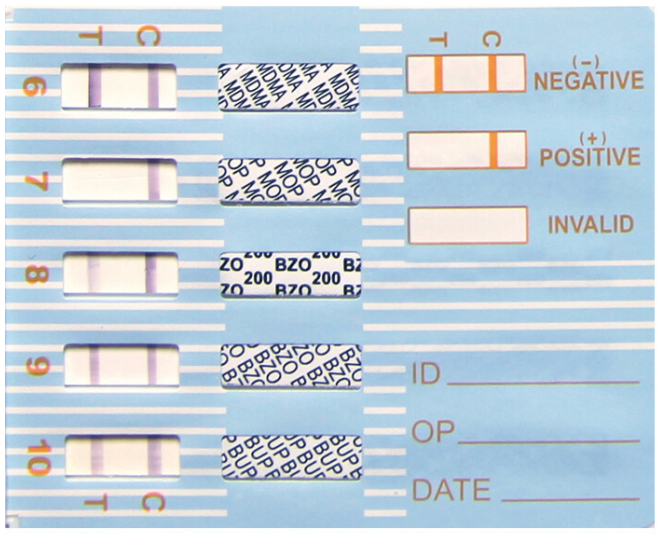

C

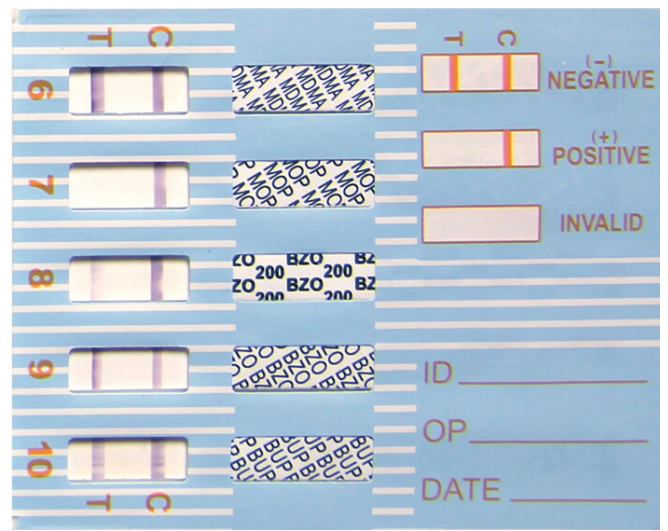

d

Figur 1 Eksempler på misvisende resultater ved hurtigtest av rusmidler. A viser falskt positivt resultat, B viser falskt negativt resultat og $\mathrm{C}$ og D viser uspesifikt prøvesvar.

\section{Hva bør man vite?}

Gullstandarden for rusmiddelanalyser er gass/væskekromatografi kombinert med massespektrometri. Med slike analysemetoder er falskt positive prøvesvar grunnet immunologiske kryssreaksjoner ikke en aktuell problemstilling. Det gjøres da helt spesifikk, separat analyse av hvert enkelt rusmiddel. Ved behov kan det også gjøres spesifikke tilleggsanalyser av forløpere og omdanningsprodukter som kan avklare nærmere hva som er inntatt. Slike analyser er tilgjengelig ved flere klinisk farmakologiske sykehuslaboratorier, hvor de fortolkes av spesialisert helsepersonell i et system underlagt streng kvalitetskontroll og kontinuerlig fagutvikling.

«Hurtigtester bør kun brukes $i$ situasjoner hvor et raskt svar er viktig, og aldri som eneste undersøkelse når et positivt testsvar kan danne grunnlag for sanksjoner»

Hurtigtester bør kun brukes i situasjoner hvor et raskt svar er viktig, og aldri som eneste undersøkelse når et positivt testsvar kan danne grunnlag for sanksjoner som tap av skoleplass, arbeid og foreldrerettigheter. Brukere må få god opplæring og ha god kunnskap om testenes begrensninger. Dette understrekes i Helsedirektoratets veileder Prosedyrer for rusmiddeltesting (3) og en supplerende rettledning for rusmiddeltesting utarbeidet av Norsk 
forening for klinisk farmakologi (4.). I sistnevnte er det en klar anbefaling om at dersom resultater fra hurtigtester har stor betydning, bør de verifiseres ved at prøven sendes til et laboratorium som utfører spesifikke rusmiddelanalyser.

\section{LITTERATUR}

1. Espnes KA, Spigset O, Delaveris GJM et al. Bruk av hurtigtester for påvisning av rusmidler i urin. Tidsskr Nor Lægeforen 2006; 126: 2257-6o. [PubMed]

2. Bjånes TK, Berg JA, Helland A et al. Rusmiddeltesting - kort forklart. Tidsskr Nor Legeforen 2019; 139. doi: 10.4045/tidsskr.18.o920. [PubMed][CrossRef]

3. Prosedyrer for rusmiddeltesting. IS-2231. Oslo: Helsedirektoratet, 2014.

https://www.helsedirektoratet.no/produkter/_/attachment/inline/d439cde8-gf43-41fa-a517-

e48dd70538d5:59987fc73bc57bab3fa76396f 42c5cd3936dd996/Prosedyrer\%2ofor\%2orusmiddeltesting\%2 o-\%20Veileder.pdf Lest 10.9.2020.

4. Farmakologiportalen. Rusmiddeltesting - en rettledning til rekvirenter.

http://www.farmakologiportalen.no/content/10124/Rusmiddeltesting Lest 27.3.2020.

Publisert: 25. september 2020. Tidsskr Nor Legeforen. DOI: 10.4045/tidsskr.20.0696

Mottatt 2.9.2020, godkjent 10.9.2020.

(C) Tidsskrift for Den norske legeforening 2023. Lastet ned fra tidsskriftet.no 26. april 2023. 